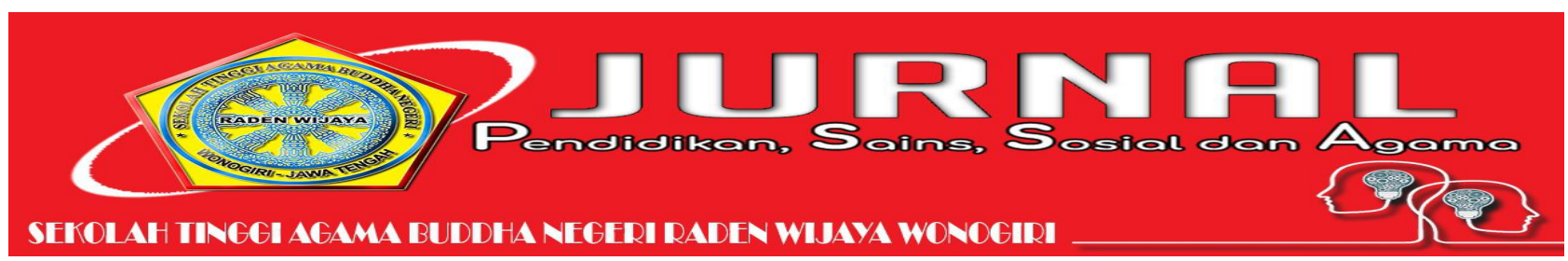

\title{
PROKRASTINASI AKADEMIK DI KALANGAN MAHASISWA PROGRAM STUDI DHARMA ACARYA
}

\author{
Andhika Mustika Dharma \\ Sekolah Tinggi Agama Buddha Maha Prajna \\ andhikamustikadharma@gmail.com
}

\begin{abstract}
Abstrak
Prokrastinasi akademik merupakan perilaku menunda-nunda mengerjakan ataupun menyelesaikan tugas-tugas akademik. Penelitian ini bertujuan memberikan gambaran mengenai prokrastinasi akademik yang dialami oleh mahasiswa. Penelitian ini merupakan jenis penelitian deskriptif dengan pendekatan kuantitatif. Penelitian ini menggunakan alat pengumpul data berupa skala prokrastinasi akademik. Penelitian dilakukan di Sekolah Tinggi Agama Buddha Maha Prajna Cilincing - Jakarta Utara. Subyek yang digunakan dalam penelitian ini adalah mahasiswa prodi Dharma Acarya sejumlah 30 mahasiswa yang di ambil dengan cara simple random sampling. Analisis data dalam penelitian ini menggunakan teknik persentase. Hasil yang diperoleh dalam penelitian ini menggambarkan kondisi prokrastinasi akademik mahasiswa pada kategori sangat tinggi sebesar 10\%, kategori tinggi sebesar $60 \%$, kategori sedang 13,3\%, kategori rendah 6,7\%, kategori sangat rendah 10\%. Prokrastinasi akademik yang dialami oleh mahasiswa tersebut terdiri dari beberapa aspek antara lain keyakinan akan kemampuan, gangguan perhatian, faktor sosial, manajemen waktu, inisiatif pribadi, dan kemalasan.
\end{abstract}

Kata kunci: prokrastinasi akademik, dysfunctional Procrastination, tugas akademik, mahasiswa

\begin{abstract}
Academic procrastination is a procrastinating behavior of doing or completing academic tasks. This study aims to provide an overview of the academic procrastination experienced by students. This research is a descriptive research with quantitative approach. This study uses data collection tool in the form of academic procrastination scales. The study was conducted at Maha Prajna Buddhist College Cilincing - Nort Jakarta. The subjects used in this study are students of dharma acarya program of 30 students taken by simple random sampling. Data analysis in this research using percentage technique. The results obtained in this study describes the condition of student academic procrastination in very high category of $10 \%$, high category of $60 \%$, medium category $13,3 \%$, low category $6,7 \%$, very low category $10 \%$. The academic procrastination experienced by the student consists of several aspects such as belief in ability, attention disturbance, social factors, time management, initiative, personal, and laziness.
\end{abstract}

Keywords: academic procrastination, dysfunctional Procrastination, academic task, students.

\section{Pendahuluan}

Disiplin dalam mengelola waktu dan juga dalam mengerjakan tugas-tugas, dikaitkan dengan sumber daya manusia yang berkualitas. Mengelola waktu berarti mengarah pada pengelolaan diri dengan berbagai cara yang bertujuan untuk mengoptimalkan waktu yang dimiliki. Artinya, seseorang menyelesaikan pekerjaan di bawah 
waktu yang tersedia sehingga mencapai hasil yang memuaskan. Menunda pengerjaan tugas, dipandang sebagian orang sebagai suatu prilaku negatif. Orang yang menunda tugas dianggap memiliki kemampuan kognitif lebih rendah dibanding kelompoknya dan tidak terlalu memperdulikan kualitas tugasnya. Mahasiswa harus berhadapan dengan tugas-tugas yang tidak sedikit dari dosen baik didalam kampus atau diluar. Situasi ini dapat menjadi sulit bagi mahasiswa yang cenderung menunda-nunda waktu dalam pengerjaan tugas dengan berpikir tetap akan lulus meski terlambat mengerjakan tugas. Studi empiris oleh Burns, Dittman, Nguyen, \& Mitchelson (2000: 3546) dan Wolters (2003: 179-187) mengungkapkan hasil dari menunda-nunda bahwa seseorang akan kehilangan waktu, kesehatan yang terganggu, dan harga diri yang rendah. Dengan menunda-nunda pekerjaan, manusia akan kehilangan kesempatan dan menyia-nyiakan karunia Tuhan, Ferrari \& Tice (2000: 1). Pada sebuah penelitian yang dilakukan oleh Ferrari \& Tice (2000: 34), prokrastinasi atau menunda-nunda dapat dikaitkan dengan kecemasan dan ketakutan terhadap kegagalan. Menunda-nunda dianggap sebagai hambatan mahasiswa dalam mencapai kesuksesan akademis karena dapat menurunkan kualitas dan kuantitas pembelajaran, menambah tingkat stres, dan berdampak negatif dalam kehidupan mahasiswa. Menurut Burka \& Yuen (2008: 165), Prokrastinasi menciptakan masalah eksternal, seperti menunda mengerjakan tugas membuat kita tidak dapat mengerjakan tugas dengan baik dan mendapat peringatan dari guru serta menimbulkan masalah internal, seperti merasa bersalah atau menyesal. Solomon dan Rothblum
(2005: 504) mengatakan: "Procrastination, the act of needlessly delaying tasks to the point of experiencing subjective discomfort, is an all-toofamiliar problem". Pernyataan ini menjelaskan bahwa suatu penundaan dikatakan sebagai prokrastinasi apabila penundaan itu dilakukan pada tugas yang penting, dilakukan berulang-ulang secara sengaja, menimbulkan perasaan tidak nyaman, serta secara subyektif dirasakan oleh seorang prokrastinator.

Prokrastinasi akademik adalah menunda-nunda pekerjaan di bidang akademis. Dampak dari prokrastinasi akademik sering diabaikan bahi sebagian mahasiswa. Banyak peneliti telah mengestimasi bahwa 46 \% Solomon dan Rothblum (2005: 505), sampai 95 \%, Ellis \& Knaus (2002: 374), hampir 70\% mahasiswa melakukan prokrastinasi, dan secara tetap melakukan prokrastinasi dalam tugas-tugas perkuliahannya. Burka \& Yuen (2008: 68) memperkirakan prokrastinasi pada mahasiswa mencapai 75\%, dengan 50\% dari siswa melaporkan bahwa mereka prokrastinasi konsisten dan menganggapnya sebagai masalah. Hasil penelitian Yudistiro (2016: 428) diketahui siswa yang memiliki prokrastinasi akademik tinggi dan sangat tinggi dengan jumlah 4 siswa atau sekitar 7.55 persen di kategori sangat tinggi dan 17 siswa atau 32,08 persen di kategori tinggi. Dalam kategori tersebut, siswa cenderung selalu menunjukan perilaku penundaan mengerjakan tugas akademik sebagai suatu pegunduran secara sengaja dan biasanya disertai dengan perasaan tidak suka untuk megerjakan sesuatu yang harus dikerjakan. Senada dengan pendapat Knaus (2002: 178), bahwa prokrastinasi dapat juga dikatakan sebagai penghindaran tugas, 
yang diakibatkan perasaan tidak senang terhadap tugas serta ketakutan untuk gagal dalam mengerjakan tugas. Mahasiswa yang melakukan prokrastinasi akademik diprediksi sangat sedikit yang memanfaatkan tenggang waktu yang diberikan untuk menyelesaikan tugas. Penundaan yang tidak disertai dengan peran adaptif mahasiswa dapat menyebabkan mahasiswa kurang berprestasi (Schraw, Watkinds, \& Olafson, 2007: 12).

Tujuan utama dalam penelitian ini adalah dapat memberikan penjelasan deskriptif yang lebih mendalam tentang prokrastinasi akademik di kalangan mahasiswa didasari pada berbagai fenomena yang dijelaskan para ahli tersebut. Pengetahuan tentang prokrastinasi akademik ini dapat dilakukan upaya pencegahan terjadinya prokrastinasi akademik berkepanjangan pada mahasiswa. Hasil penelitian ini dapat dijadikan sebagai bahan informasi bagi perguruan tinggi agama Buddha dalam meminimalisir akibat yang ditimbulkan dari prokrastinasi akademik tersebut serta upaya meningkatkan akademik mahasiswa.

Tugas merupakan suatu bentuk kegiatan di akademik yang harus diselesaikan oleh mahasiswa sebagai syarat pembelajaran. Ferrari (Nugrasanti, 2006: 26) mengemukakan bahwa menunda tugas akademik disebut dengan prokrastinasi akademik, yaitu suatu perilaku untuk menunda-nunda mengerjakan ataupun menyelesaikan tugas-tugas akademik. Prokrastinasi berasal dari bahasa latin "procrastination' dengan awalan 'pro' yang berarti mendorong maju atau bergerak maju dan akhiran 'crastinate' yang berarti "kepunyaan hari esok", atau jika digabungkan maka artinya menjadi "menangguhkan atau menunda sampai hari berikutnya" (DeSimone, dalam Ferrari, dkk 1995: Asosiasi Dosen \& Unit Penelitian dan Pengabdian Masyarakat
4). Burka \& Yuen menyampaikan, awalan 'pro' yang berarti forward atau meneruskan atau mendorong kedepan, dan akhiran 'crastinus' yang berarti belonging to tomorrow atau milik hari esok. Jika digabungkan menjadi "procastinus" yang mempunyai arti forward it to tomorrow (meneruskan hari esok) atau dengan kata lain berarti "saya akan melakukannya nanti” (Burka \& Yuen, 2008: 5). Ferrari, J, R, dkk (1995: 8) membagi prokrastinasi menjadi dua berdasarkan jenis tugasnya, yaitu (1) prokrastinasi akademik, adalah jenis penundaan yang dilakukan pada jenis tugas formal yang berhubungan dengan tugas akademik. Sebagai contoh penundaan terhadap tugas kuliah atau tugas kursus. (2) Prokrastinasi non-akademik, adalah penundaan yang dilakukan pada jenis tugas non formal atau berhubungan dengan kehidupan sehari-hari. Penelitian ini menggunakan jenis prokrastinasi akademik. Pelaku dari prokrastinasi mengarah pada mahasiswa yang sedang kuliah dan individu yang mengalami proses akademik. Mahasiswa akan dihadapkan pada berbagai tuntutan dan tugas, baik di kampus maupun di luar kampus. Tuntutan ini mengharuskan mahasiswa untuk berkemampuan dalam mengatur diri untuk menyelesaikannya. Mahasiswa yang mampu mengatur diri dan menyelesaikan tugas-tugasnya, akan terhindar dari perilaku prokrastinasi.

Millhgram (dalam Ilfiandra, 2010: 2) mengatakan bahwa prokrastinasi adalah suatu perilaku spesifik yang meliputi:

1. Suatu perilaku yang melibatkan unsur penundaan, baik untuk memulai maupun menyelesaikan suatu tugas atau aktivitas 
2. Menghasilkan akibat-akibat lain yang lebih jauh, misalnya keterlambatan menyelesaikan tugas maupun kegagalan dalam mengerjakan tugas

3. Melibatkan suatu tugas yang dipersepsikan oleh pelaku prokrastinasi sebagai suatu tugas yang penting untuk dikerjakan, misalnya tugas kantor, tugas kampus, maupun tugas rumah tangga

4. Menghasilkan keadaan emosional yang tidak menyenangkan, misalnya perasaan cemas, perasaan bersalah, marah, panik, dan sebagainya.

Menurut Solomon dan Rothblum (2005: 506), jenis tugas yang menjadi objek prokrastinasi akademik adalah penundaan tugas menulis, seperti menulis makalah, laporan atau mengarang. Kemudian pada tugas belajar untuk menghadapi ujian. Prokrastinasi pada tugas membaca buku atau referensi yang diwajibkan. Prokrastinasi pada tugas administratif, seperti menyalin catatan, mengisi daftar hadir di kelas dan praktikum. Kemudian prokrastinasi menghadiri pembelajaran, sering terlambat kuliah, praktikum dan pertemuanpertemuan lainnya. Pendapat mengenai prokrastinasi akademik selanjutnya dikemukakan oleh Wolter (2003: 95) bahwa "prokrastinasi akademik merupakan kegagalan dalam mengerjakan tugas akademik dalam kerangka waktu yang diinginkan atau menunda mengerjakan tugas sampai saat-saat terakhir". Penundaan mengerjakan tugas yang berkepanjangan tentu dapat mengganggu produktivitas individu dan dapat mengganggu kondisi individu secara psikis.

Orang yang melakukan prokrastinasi disebut sebagai procrastinator dan dilakukan dengan alasan Asosiasi Dosen \& Unit Penelitian dan Pengabdian Masyarakat yang berbeda-beda. Perbedaan alasan dan tujuan dari prokrastinator membuat para ahli mengelompokkan prokrastinasi ke dalam beberapa jenis. Ferrari (dalam Ghufron, 2010: 154-155) membagi prokrastinasi berdasarkan tujuan dan manfaat penundaannya, yaitu:

1. Functional Procrastination, yaitu penundaan dalam mengerjakan tugas yang bertujuan untuk memperoleh informasi yang lebih lengkap dan akurat. Prokrastinasi fungsional ini biasanya dilakukan untuk mengumpulkan data-data penting, referensi atau informasi lain yang terkait dengan tugas primer (tugas yang penting). Dalam kenyatananya, untuk mengumpulkan data-data memang membutuhkan waktu yang tidak pasti sesuai dengan jenis informasi yang akan dicari. Ada informasi yang membutuhkan waktu sebentar, dan ada juga yang lama. Prokrastinasi macam ini sering terjadi pada tugas-tugas yang berhubungan dengan penelitian.

2. Dysfunctional Procrastination, yaitu penundaan mengerjakan tugas yang tidak bertujuan, berakibat buruk dan menimbulkan masalah. Bentuk penundaan ini tanpa disertai suatu alasan yang berguna bagi procrastinator maupun orang lain. Penundaan ini dapat menimbulkan masalah bila procrastinator tidak bisa melepaskan diri dari kebiasaan penundaan tersebut

Ada dua bentuk Dysfunctional procrastination berdasarkan tujuan mereka melakukan penundaan (dalam Rizvi dkk., 1997: 18), yaitu (a) Decisional Procrastination; (b) Avoidance Procrastination atau Behavioral Procrastination.

1. Decisional Procrastination 
Suatu penundaan dalam mengambil keputusan. Hal ini terjadi akibat kegagalan dalam mengidentifikasi tugas yang yang menyebabkan konflik dalam diri individu dan memutuskan untuk menunda. Bentuk prokrastinasi ini merupakan sebuah antesenden kognitif dalam menunda untuk memulai melakukan suatu pekerjaan dan dilakukan sebagai suatu bentuk coping yang digunakan untuk menyesuaikan diri dalam menghadapi situasi yang dipersepsikan penuh stress. Decisional procrastination berhubungan dengan kelupaan, kegagalan proses kognitif, akan tetapi tidak berkaitan dengan kurangnya tingkat intelegensi seseorang (Ferrari dalam Wulan, 2000: 43).

\section{Avoidance Procrastination atau Behavioral}

\section{Procrastination}

Suatu penundaan dalam perilaku yang tampak. Penundaan ini dilakukan sebagai suatu cara untuk menghindari tugas yang dirasakan kurang menyenangkan dan sulit untuk dilakukan. Hal ini dilakukan untuk menghindari kegagalan yang akan memberikan penilaian negatif kepada dirinya. Avoidance Procrastination berhubungan dengan tipe self presentation, keinginan untuk menjauhkan diri dari tugas yang menantang, dan implusiveness (Ferrari dalam Wulan, 2000: 44).

Bruno (1998: 23), menjelaskan bahwa ada empat jenis prokrastinasi, yaitu:

1. Penundaan fungsional, adalah penundaan yang dilakukan pada saat yang tepat dan bertujuan, atau adanya kegiatan lain yang lebih tinggi prioritasnya, misalnya individu yang menunda tugasnya karena sakit.
2. Penundaan disfungsional, adalah penundaan yang tidak bertujuan dan tidak berguna, akibatnya tugas-tugas tidak terselesaikan, kesempatan hilang dan tujuan tidak tercapai. Misalnya, menunda kerena takut gagal.

3. Penundaan jangka pendek, adalah penundaan pada target waktu yang pendek. Misalnya, jam atau harian.

4. Penundaan kronis, adalah penundaan yang telah menjadi kebiasaan, sulit dihentikan, menjadi masalah dan sangat merugikan.

Para ahli menyampaikan jenis dan bentuk prokrastinasi berdasarkan tujuannya. Berdasarkan penyampaian para ahli, penelitian prokrastinasi ini hanya dibatasi pada bentuk Dysfunctional Procrastination yaitu penundaan yang mengakibatkan kerugian dan dampak negatif bagi seseorang baik pada bentuk Decisional Procrastination maupun Aviodance Procrastination. Penundaan ini adalah penundaan yang tidak bertujuan dan tidak berguna, akibatnya tugas-tugas tidak terselesaikan, kesempatan hilang dan tujuan tidak tercapai. Menurut Mccloskey (2011) karakteristik prokrastinasi akademik antara lain: keyakinan psikologis tentang kemampuan (tantangan dan tekanan), gangguan, faktor sosial, manajemen waktu, inisiatif pribadi dan kemalasan.

Munculnya prokrastinasi akademik dalam diri mahasiswa diprediksi tidak terjadi begitu saja, namun terdapat penyebab yang melatarbelakangi. Menurut Ferrari, Johnson, \& Mc Cown (1995: 81) menyebutkan bahwa penyebab perilaku prokrastinasi adalah: 1) Adanya pikiran irrasional dari prokrastinator, yaitu anggapan bahwa suatu 
tugas harus diselesaikan dengan sempurna. 2)

Adanya kecemasan karena kemampuannya dievaluasi, ketakutan akan kegagalan dan susah mengambil keputusan, atau karena membutuhkan bantuan orang lain untuk mengerjakan tugasnya. 3) Malas dan kesulitan mengatur waktu dan tidak menyukai tugasnya. 4) Adanya punishment dan reward juga dapat menyebabkan prokrastinasi sehingga merasa lebih aman jika tidak melakukan dengan segera karena dapat menghasilkan sesuatu yang tidak maksimal. 5) Adanya faktor lingkungan, yaitu kurangnya pengamatan dari lingkungan seperti keluarga atau di lingkungan sekolah juga menyebabkan seseorang melakukan prokrastinasi. 6) Selain itu prokrastinasi disebabkan karena tugas yang menumpuk, terlalu banyak dan harus segera dikerjakan, sehingga penundaan tugas yang satu dapat menyebabkan tugas lain tertunda.

Menurut pandangan teori Reinforcement menyatakan bahwa prokrastinator tidak pernah atau jarang menerima hukuman. Bahkan seorang pelaku prokrastinator merasa diuntungkan karena dengan menunda pengerjaan suatu tugas pada akhirnya selesai juga. Sedangkan teori cognitive behavioral menjelaskan bahwa perilaku menunda akibat dari kesalahan dalam berpikir dan adanya pikiranpikiran yang irasional terhadap tugas seperti takut gagal dalam penyelesaian suatu tugas (ferari \& Morales, 2007: 91-96). Seseorang dikatakan melakukan prokrastinasi apabila ia menunjukkan ciri-ciri antara lain takut gagal, impulsif, perfeksionis, pasif dan menunda-menunda sehingga melebihi tenggat waktu (Randy, 2008: 56-67).

Sebagai perilaku yang cenderung bermakna negatif, perilaku prokrastinasi dapat memberikan dampak yang merugikan, baik bagi diri pelaku Asosiasi Dosen \& Unit Penelitian dan Pengabdian Masyarakat maupun bagi orang lain di sekitarnya. Sebagaimana dikemukakan oleh beberapa ahli berikut, menurut Burka \& Yuen (2008: 52), prokrastinasi mengganggu dalam dua hal. Pertama, perilaku penundaan atau prokrastinasi ini dapat menciptakan masalah eksternal, seperti menunda mengerjakan tugas dan terlambat mengumpulkannya, maka pihak yang memberikan tugas akan dihadapkan pada proses tindak lanjut dari tugas yang telah dikumpulkannya tersebut juga terhambat (misalnya, proses evaluasi akan tertunda). Dampak lainnya adalah berbagai pihak yang terlibat dalam penyelesaian tugas juga akan dirugikan, karena jadwal mereka akan berubah semua, tugas-tugas mereka yang lain akan tertunda juga, karena penundaan yang dilakukan oleh prokastinator. Kedua, mendatangkan masalah internal, pelaku penundaan mendapat peringatan dari pihak pemberi tugas (misalnya dosen) sebagai punishment atau keterlambatannya mengumpulkan tugas yang diterimanya. Setelah mendapat punishment teguran atau bahkan pengurangan nilai, maka masalah internalnya dapat berupa perasaan bersalah atau menyesal.

Kerugian lain yang ditimbulkan dari sikap prokrastinasi akademik adalah tugas tidak terselesaikan, atau terselesaikan namun hasilnya tidak maksimal, karena dikejar deadline. Menimbulkan kecemasan sepanjang waktu pengerjaan tugas, sehingga jumlah kesalahan tinggi karena individu mengerjakan dalam waktu yang sempit. Di samping itu, sulit berkonsentrasi karena ada perasaan cemas, sehingga motivasi belajar dan kepercayaan diri menjadi rendah.

Berbagai pendapat yang disampaikan para ahli tentang prokrastinasi akademik, peneliti 
menyimpulkan prokrastinasi akademik sebagai kegiatan menunda pengerjaan tugas-tugas dengan waktu dan alasan penundaan yang beragam, dipengaruhi oleh berbagai faktor dan kondisi. Karakteristik prokrastinasi akademik yang dimaksud dalam penelitian ini berupa keyakinan psikologis tentang kemampuan (tantangan dan tekanan), gangguan, faktor sosial, manajemen waktu, inisiatif pribadi dan kemalasan.

\section{Metode Penelitian}

Penelitian ini merupakan jenis penelitian deskriptif dengan pendekatan kuantitatif. Sugiyono (2012: 8) menjelaskan tentang deskriptif kualitatif yaitu "Metode penelitian yang berlandaskan pada filsafat positivisme, digunakan untuk meneliti pada populasi atau sampel tertentu, pengumpulan data menggunakan instrumen penelitian, analisis data bersifat kuantitatif/statistik, dengan tujuan untuk menguji hipotesis yang telah ditetapkan”. Penelitian ini bertujuan untuk memberikan penjelasan deskriptif yang lebih mendalam tentang prokrastinasi akademik di kalangan mahasiswa. Subyek yang digunakan dalam penelitian ini adalah mahasiwa prodi Dharma Acarya sejumlah 30 mahasiswa yang di ambil dengan cara simple random sampling. Teknik pengumpulan data dalam penelitian ini menggunakan teknik nontes dengan instrumen berupa skala prokrastinasi akademik dengan lima kategori jawaban, yaitu sangat tinggi, tinggi, sedang, rendah, dan sangat rendah. Selanjutnya, analisis data dalam penelitian ini menggunakan rumus persentase agar memperoleh gambaran mengenai kondisi prokrastinasi yang dialami mahasiswa.

Peneliti menyiapkan 2 jenis instrument, untuk menentukan frekuensi prokrastinasi akademik mahasiswa prodi Dharma Acarya dan persentase indikator yang mempengaruhi prokrastinasi akademik mahasiswa. Instrument pertama berisi pertanyaan sejumlah 32 butir dengan skor masingmasing kategori jawaban 1-5 untuk mengetahui frekuensi prokrastinasi akademik mahasiswa prodi Dharma Acarya. Instrument kedua berisi pertanyaan dengan pilihan jawaban berupa kategori prokrastinasi akademik, untuk menentukan secara detail persentase indikator prokrastinasi akademik mahasiswa prodi Dharma Acarya. Indikator yang digunakan adalah karakteristik prokrastinasi akademik menurut Mccloskey yaitu keyakinan psikologis tentang kemampuan (tantangan dan tekanan), gangguan, faktor sosial, manajemen waktu, inisiatif pribadi dan kemalasan.

\section{Hasil dan Pembahasan}

Hasil analisis data prokrastinasi akademik mahasiswa secara umum dikategorisasikan menjadi beberapa kategori. Adapun profil prokrastinasi akademik mahasiswa prodi Dharma Acarya dapat dilihat pada tabel 1 berikut ini.

Tabel 1

Distribusi frekuensi prokrastinasi akademik mahasiswa prodi Dharma Acarya

\begin{tabular}{|l|l|l|}
\hline Kategori & Interval & Frekuensi \\
\hline Sangat Tinggi & $132-160$ & 3 \\
\hline
\end{tabular}




\begin{tabular}{|l|l|l|}
\hline Tinggi & $107-131$ & 18 \\
\hline Sedang & $82-106$ & 4 \\
\hline Rendah & $57-81$ & 2 \\
\hline Sangat Rendah & $32-56$ & 3 \\
\hline Total & $\mathbf{3 0}$ \\
\hline
\end{tabular}

Pada tabel 1 diketahui bahwa dari jumlah total 30 mahasiswa, terdapat sejumlah 3 mahasiswa yang memiliki prokrastinasi akademik pada kategori sangat tinggi dan 18 mahasiswa yang berada pada kategori tinggi. Mahasiswa yang memiliki prokrastinasi sedang sebanyak 4 mahasiswa, rendah sebanyak 2 mahasiswa dan 3 mahasiswa yang memiliki prokrastinasi pada kategori sangat rendah. Hasil analisis tersebut menunjukkan bahwa kategori terbanyak terkait dengan prokrastinasi akademik mahasiswa berasal pada kategori tinggi, yaitu sejumlah 18 mahasiswa. Data ini diperoleh menggunakan instrument sebanyak 32 pertanyaan dengan skala skor $1-5$. Data prokrastinasi akademik mahasiswa yang telah terkumpul melalui skala prokrastinasi akademik, selanjutnya dilakukan analisis dengan menggunakan rumus persentase. Berdasarkan hasil analisis data diperoleh rincian gambaran mengenai kondisi prokrastinasi akademik yang dialami oleh mahasiswa Dharma Acarya. Gambaran prokrastinasi akademik dapat diketahui melalui gambar 1 berikut ini.

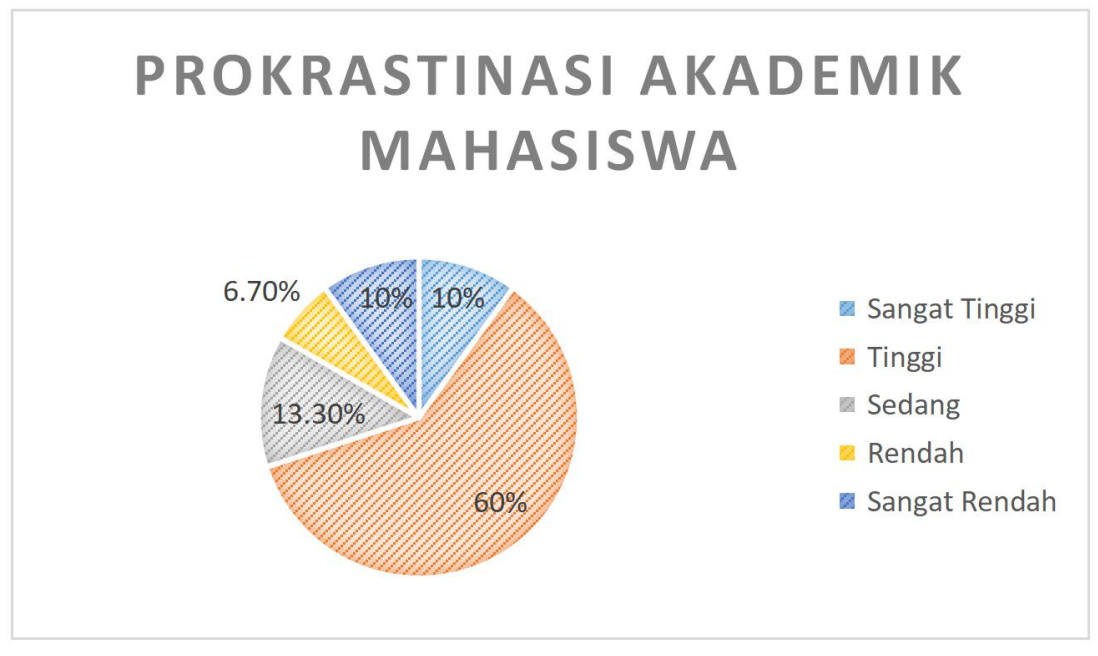

Gambar 1

Persentase prokrastinasi akademik mahasiswa prodi Dharma Acarya

Berdasarkan hasil persentase prokrastinasi akademik tersebut dapat diketahui bahwa sebagian besar mahasiswa memiliki prokrastinasi akademik pada kategori tinggi sebesar 60\%. Jika dibandingkan dengan kategori lain, kategori tinggi ini lebih mendominasi kondisi prokrastinasi akademik mahasiswa prodi Dharma Acarya. Sedangkan kategori yang lain, cenderung hampir seimbang. Dalam kategori sangat tinggi terdapat 10\% mahasiswa. Mahasiswa kondisi prokrastinasi 
akademik yang berada pada kategori sangat rendah terdapat $10 \%$, atau memiliki persentase yang sama dengan kategori sangat tinggi. Idealnya kondisi sangat rendah inilah yang seharusnya dikembangkan oleh mahasiswa prodi Dharma Acarya. Hasil analisis lainnya dari data yang diperoleh menunjukkan hanya $6,7 \%$ mahasiswa yang memiliki kondisi prokrastinasi akademik pada kategori rendah dan $13,3 \%$ mahasiswa dalam kondisi prokrastinasi akademik pada kategori sedang.

Data prokrastinasi akademik mahasiswa dilakukan secara lebih mendetail, dengan mencari persentase indikator. Berikut pemaparan prokrastinasi akademik mahasiswa pada masingmasing indikator yang dapat dilihat pada tabel 2 berikut ini

Tabel 2

Persentase Prokrastinasi Akademik pada Masing-masing Indikator

\begin{tabular}{|c|c|c|c|c|c|c|c|c|c|c|c|c|}
\hline \multirow[t]{3}{*}{ Kategori } & \multicolumn{12}{|c|}{ Prokrastinasi Akademik } \\
\hline & \multicolumn{2}{|c|}{$\begin{array}{l}\text { Keyakinan } \\
\text { akan } \\
\text { kemampuan }\end{array}$} & \multicolumn{2}{|c|}{$\begin{array}{l}\text { Gangguan } \\
\text { perhatian }\end{array}$} & \multicolumn{2}{|c|}{ Faktor sosial } & \multicolumn{2}{|c|}{$\begin{array}{l}\text { Manajemen } \\
\text { waktu }\end{array}$} & \multicolumn{2}{|c|}{$\begin{array}{l}\text { Inisiatif } \\
\text { pribadi }\end{array}$} & \multicolumn{2}{|c|}{ Kemalasan } \\
\hline & $\mathrm{F}$ & $\%$ & $\mathrm{~F}$ & $\%$ & $\mathrm{~F}$ & $\%$ & $\mathrm{~F}$ & $\%$ & $\mathrm{~F}$ & $\%$ & $\mathrm{~F}$ & $\%$ \\
\hline $\begin{array}{l}\text { Sangat } \\
\text { tinggi }\end{array}$ & 3 & $10 \%$ & 1 & $3,3 \%$ & 0 & $0 \%$ & 7 & $23,3 \%$ & 4 & $13,3 \%$ & 10 & $33,4 \%$ \\
\hline Tinggi & 13 & $43,3 \%$ & 16 & $53,3 \%$ & 10 & $33,4 \%$ & 16 & $53,3 \%$ & 17 & $56,7 \%$ & 12 & $40 \%$ \\
\hline Sedang & 6 & $20 \%$ & 8 & $26,8 \%$ & 13 & $43,3 \%$ & 3 & $10 \%$ & 2 & $6,7 \%$ & 7 & $23,3 \%$ \\
\hline Rendah & 3 & $10 \%$ & 1 & $3,3 \%$ & 6 & $20 \%$ & 2 & $6,7 \%$ & 3 & $10 \%$ & 0 & $0 \%$ \\
\hline $\begin{array}{l}\text { Sangat } \\
\text { rendah }\end{array}$ & 5 & $16,7 \%$ & 4 & $13,3 \%$ & 1 & $3,3 \%$ & 2 & $6,7 \%$ & 4 & $13,3 \%$ & 1 & $3,3 \%$ \\
\hline
\end{tabular}

Tabel 2 di atas menggambarkan kondisi prokrastinasi akademik yang berdasar jumlah mahasiswa dengan skor persentase pada masingmasing indikator prokrastinasi akademik. Pertama, pada indikator keyakinan akademik memiliki persentase tertinggi pada kategori tinggi. Kedua, pada indikator gangguan perhatian memiliki persentase tertinggi pada kategori tinggi. Ketiga, pada indikator faktor sosial memiliki persentase tertinggi pada kategori sedang. Keempat, pada indikator manajemen waktu memiliki persentase tertinggi pada kategori tinggi. Kelima, pada indikator inisiatif pribadi memiliki persentase tertinggi pada kategori tinggi. Keenam, pada indikator terakhir yaitu indikator kemalasan memiliki kategori persentase tertinggi pada kategori tinggi.

Berdasarkan masing-masing kategori, table 2 menggambarkan persentase tertinggi masingmasing kategori terhadap indikator prokrastinasi akademik. Pertama, pada kategori sangat tinggi memiliki persentase tertinggi adalah indikator 
kemalasan yaitu 33,4\%. Kedua, pada kategori tinggi

memiliki persentase tertinggi adalah indikator inisiatif pribadi yaitu $56,7 \%$. Ketiga, pada kategori sedang memiliki persentase tertinggi adalah indikator faktor sosial yaitu 43,3\%. Keempat, pada kategori rendah memiliki persentase tertinggi adalah indikator faktor sosial yaitu $20 \%$. Kelima, pada kategori sangat rendah memiliki persentase tertinggi adalah indikator keyakinan yaitu 16,7\%.

Pada tabel 2 dimaknai bahwa prokrastinasi akademik yang paling banyak terjadi pada mahasiswa terdapat pada indikator kemalasan dengan persentase $33,4 \%$ atau sebanyak 10 dari 30 mahasiswa dengan kategori sangat tinggi. Prokrastinasi akademik paling sedikit dialami mahasiswa terdapat pada indikator faktor sosial yaitu sebesar $0 \%$ atau sebanyak 0 dari 30 mahasiswa atau tidak ada.
Rata-rata pengaruh setiap kategori terhadap prokrastinasi akademik berdasarkan seluruh indikator, didapat data persentase. Pertama, persentase pengaruh kategori sangat tinggi terhadap prokrastinasi akademik adalah 13,88\%. Kedua, persentase pengaruh kategori tinggi terhadap prokrastinasi akademik adalah 46,68\%. Ketiga, persentase pengaruh kategori sedang terhadap prokrastinasi akademik adalah 21,68\%. Keempat, persentase pengaruh kategori rendah terhadap prokrastinasi akademik adalah 8,33\%. Kelima, persentase pengaruh kategori sangat rendah terhadap prokrastinasi akademik adalah 9,43\%. Data ini didapat dari persentase rata-rata setiap kategori dari persentase masing-masing indikator. Persentase prokrastinasi akademik mahasiswa pada masing-masing indikator disajikan dalam gambar 2 berikut ini.

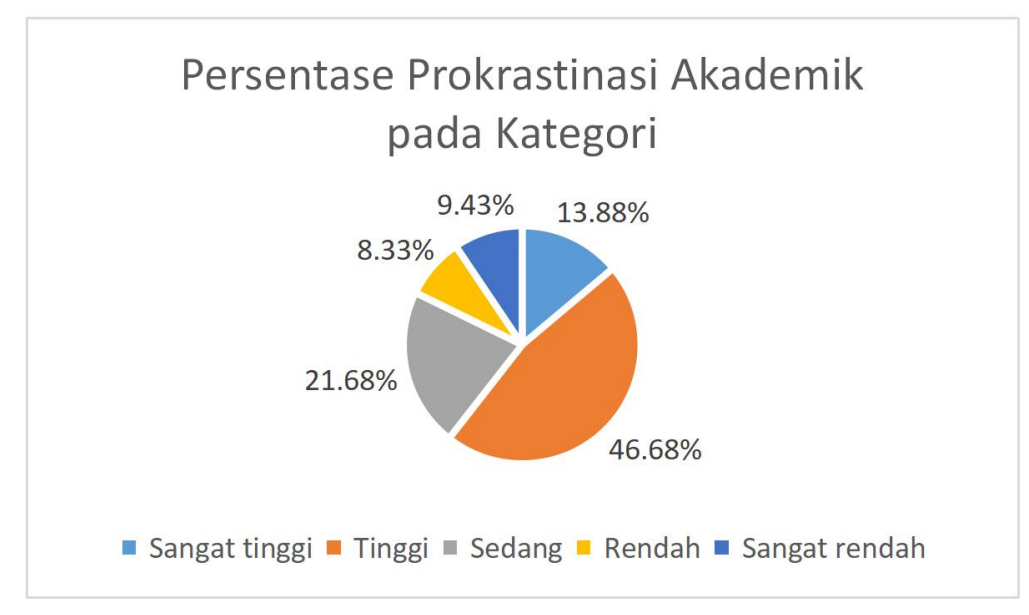

Gambar 2

Persentase Prokrastinasi Akademik mahasiswa pada masing-masing kategori

Data pada tabel 2 menunjukkan persentase dari pengaruh masing-masing indikator terhadap prokrastinasi akademik mahasiswa. Masing-masing indikator mempunyai pengaruh hampir seimbang, dengan persentase indikator kemalasan tertinggi Asosiasi Dosen \& Unit Penelitian dan Pengabdian Masyarakat sebesar 20,3\%. Indikator paling rendah mempengaruhi prokrastinasi mahasiwa adalah faktor sosial dengan 13,9\%. Manajemen waktu menjadi indikator kedua terbesar dengan 18,9\%, dilanjutkan inisiatif pribadi dengan 16,6\%, 73 
gangguan perhatian dengan $15,5 \%$ dan keyakinan

akan kemampuan sebesar 14,8\%. Untuk lebih jelasnya, data dapat dilihat pada gambar 3 berikut ini.

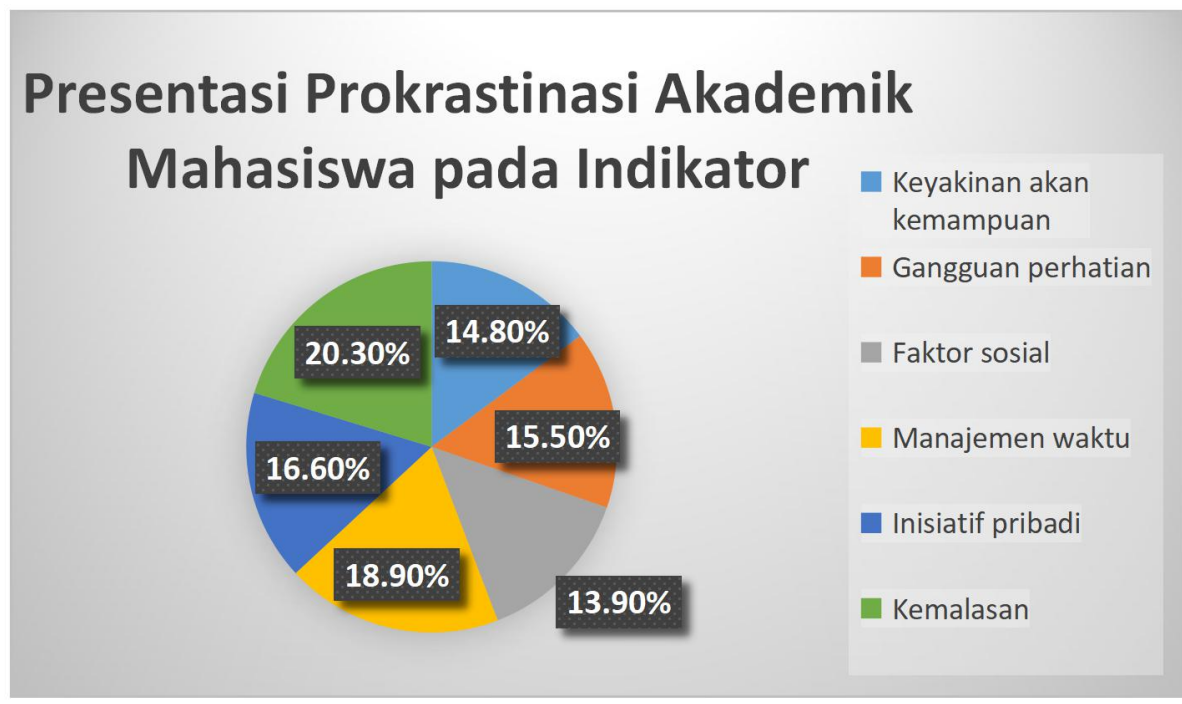

Gambar 3

Persentase prokrastinasi Akademik Mahasiswa pada Masing-masing Indikator.

Hasil analisis gambar 3 dapat dijelaskan sebagai berikut:

1. Keyakinan akan kemampuan

Keyakinan akan kemampuan diri atau selfefficacy adalah konsep utama yang besar pengaruhnya terhada perilaku. keyakinan pribadi seseorang akan seberapa besar kemungkinan dirinya akan berhasil, berdasarkan keyakinan akan kemampuan dirinya, dalam mengatasi situasi yang sulit. Bagaimana mahasiswa memandang kemampuan dirinya dalam menyelesaikan tugas-tugas akademik. Keyakinan mahasiswa akan kemampuan diri memberi kontribusi terhadap prokrastinasi akademik sebesar 14,8\%

2. Gangguan perhatian

Konsentrasi dibutuhkan dalam pengerjaan tugas sebagai pemusatan perhatian terhadap suatu objek. Apabila terjadi gangguan perhatian baik faktor secara internal ataupun eksternal, maka akan memunculkan kesulitan untuk berkonsentrasi. Dengan gangguan yang berlebihan dari berbagai sisi, fokus kita tidak akan sepenuhnya tertera pada satu aktivitas saja, melainkan terbagi-bagi atas semua yang sedang dilakukan, dan sebuah tugas bisa tertinggal atau kurang mendapat perhatian dibandingkan tugas lainnya. Pada penelitian ini gangguan perhatian memberikan kontribusi sebesar $15,5 \%$ terhadap prokrastinasi akademik mahasiswa.

3. Faktor sosial

Faktor sosial seringkali akan berpengaruh terhadap permasalahan yang dialami mahasiswa, salah satunya prokrastinasi. Sebagian orang melakukan prokrastinasi sebagai akibat gangguan aktivitas sosial untuk menunda-nunda dan bersenang-senang 
melakukan prokrastinasi dengan santai. Aktivitas sosial ini biasa dilakukan dengan keluarga teman atau rekan kerja. Mereka meyakini dengan menunda tugas, tetap akan sukses nantinya. Pada panelitian ini, faktor sosial memberikan kontribusi sebesar 13,9\% terhadap prokrastinasi akademik mahasiswa

4. Manejemen waktu

Waktu adalah tantangan besar bagi prokrastinator. Mereka cenderung menikmati waktu dan menganggap waktu bukan masalah sama sekali. Kemampuan mahasiswa dalam mengelola waktu cenderung menjadi kontribusi terbesar dalam prokrastinasi akademik mahasiswa. Pengetahuan manajemen waktu belajar yang baik adalah, tanpa memberikan tekanan atau paksaan untuk mencapai target tertentu yang harus dicapai. Terjadinya prokrastinasi ditandai adanya waktu yang tertunda dari pengerjaan tugas-tugas. Hal tersebut dibuktikan dari hasil penelitian ini bahwa manajemen waktu memberikan kontribusi sebesar $\quad 18,9 \% \quad$ terhadap prokrastinasi akademik mahasiswa.

5. Inisiatif pribadi

Inisiatif pribadi merupakan kemampuan individu dalam memutuskan sesuatu yang benar tanpa harus diberi tahu oleh orang lain. Inisiatif pribadi identik dengan motivasi internal. Jika mahasiswa kurang inisiatif, mereka tidak dapat menyelesaikan tugas dengan tepat waktu. Apabila mahasiswa memberikan kesempatan pada dirinya untuk menunda-nunda maka dapat kehilangan semangat untuk selamanya. Inisiatif pribadi dalam penelitian ini memberikan kontribusi Asosiasi Dosen \& Unit Penelitian dan Pengabdian Masyarakat sebesar $16,6 \%$ terhadap prokrastinasi akademik masiswa.

6. Kemalasan

Malas sebagai salah satu penyebab utama mahasiswa melakukan prokrastinasi. Malas dipandang sebagai konsekuensi dari kebosanan sehingga dapat memicu prilaku menundanunda. Dalam penelitian ini, kemalasan menjadi indikator terbesar dalam persentase keterlibatan. Tidak ingin atau belum termotivasi untuk melakukan apapun termasuk menyelesaikan tugas-tugas akademik juga merupakan kendala mahasiswa. Oleh karenanya, kemalasan juga berkontribusi dalam prokrastinasi akademik mahasiswa sebesar $20,3 \%$.

Secara keseluruhan, hasil penelitian prokrastinasi menunjukkan beberapa data sebagai berikut:

1. Dari 30 sampling mahasiswa terdapat 3 mahasiswa atau $10 \%$ yang masuk sebagai kategori sangat tinggi dengan interval antara 132-160. Artinya terdapat mahasiswa program studi Dharma Acarya di STAB Maha Prajna yang mengalami penundaan tugas dalam waktu sangat lama, dengan jumlah tugas yang banyak dan dapat berakibat pada terganggunya kegiatan akademik

2. Dari 30 sampling mahasiswa terdapat 18 mahasiswa atau 60\% masuk sebagai kategori tinggi dengan interval 107-131. Artinya mahasiswa program studi Dharma Acarya di STAB Maha Prajna hampir semua pernah menunda tugas dalam kurun waktu yang cukup lama dengan jumlah yang cukup bnyak. Kategori tingkat tinggi ini juga sangat 
berpengaruh terhadap kondisi stress mahasiswa dan berpengaruh pada kegiatan akademik.

3. Dari 30 sampling mahasiswa terdapat 4 mahasiswa atau 13,3\% masuk sebagai kategori sedang dengan interval 82-106. Artinya mahasiswa program studi Dharma Acarya di STAB Maha Prajna ada yang menunda pengerjaan tugas namun tidak sampai batas waktu yang ditentukan untuk pengumpulan tugas tersebut. Kategori tingkat sedang ini masih dapat berpengaruh terhadap tingkat stress mahasiswa dan kegiatan akademik

4. Dari 30 sampling mahasiswa terdapat 2 mahasiswa atau 6,7\% masuk sebagai kategori rendah dengan interval 57-81. Artinya mahasiswa program studi Dharma Acarya di STAB Maha Prajna ada yang tidak langsung mengerjakan tugas kuliah, namun dikerjakan dengan tepat waktu dan tidak menunda terlalu lama. Kondisi ini masih terbilang sangat wajar, sebab tidak semua mahasiswa mempunyai waktu untuk langsung mengerjakan tugas. Mahasiswa juga perlu waktu untuk mengistirahatkan pikiran setelah mendapat pembelajaran materi sebelum mengerjakan tugas-tugas.

5. Dari 30 sampling mahasiswa terdapat 3 mahasiswa atau $10 \%$ masuk sebagai kategori sangat rendah dengan interval 32-56. Artinya mahasiswa program studi Dharma Acarya di STAB Maha Prajna menganggap serius suatu tugas yang didapat sehingga pengerjaannya harus segera dilakukan. Mahasiswa juga menyadari bahwa penundaan tugas, hanya akan menambah beban bagi mahasiswa itu sendiri kedepannya. Karena untuk selanjutnya, aka Asosiasi Dosen \& Unit Penelitian dan Pengabdian Masyarakat nada tugas-tugas lain yang diberikan oleh dosen. Dosen berjumlah tidak sedikit, jika setiap dosen memberikan satu tugas, maka akan semakin memberatkan bagi mahasiswa dalam pengerjaannya, jika tidak segera diselesaikan. Kondisi kategori sangat rendah ini, sangat ideal bagi setiap mahasiswa program studi tidak hanya di STAB Maha Prajna, namun diseluruh pergurun tinggi agama Buddha. Tidak ada orang yang sukses dengan terus menerus menunda tugas tanpa alasan yang tepat.

6. Dalam indikator, terdapat faktor sosial yang tidak memiliki frekuensi pada kategori sangat tinggi, yaitu 0 mahasiswa atau $0 \%$ dalam pesentase dan berada pada kategori sedang untuk frekuensi tertinggi, yaitu 13 mahasiswa atau $43,3 \%$. Hal ini dapat menunjukkan adanya sikap tidak terpengaruh oleh mahasiswa terhadap kegiatan mahasiswa lainnya. Namun sikap terpengaruh ini tetap ada dan dilakukan oleh mahasiswa sehingga terdapat frekuensinya mencapai 10 mahasiswa atau 33,4\%

7. Indikator kemalasan menjadi indikator tertinggi yang paling mempengaruhi prokrastinasi akademik mahasiswa dengan frekuensi 10 mahasiswa atau $33,4 \%$.

8. Rata-rata kategori indikator prokrastinasi akademik mahasiswa masuk ke dalam kategori tinggi dengan rata-rata persentase mencapai $46,68 \%$ atau dengan rata-rata frekuensi 14 mahasiswa.

9. Kategori sangat tinggi untuk indikator prokrastinasi akademik mahasiswa rata-rata persentase mencapai $13,88 \%$ atau dengan ratarata frekuensi 4,2 mahasiswa. 
10. Kategori sedang untuk indikator prokrastinasi akademik mahasiswa rata-rata persentase mencapai $21,68 \%$ atau dengan rata-rata frekuensi 6,5 mahasiswa.

11. Kategori rendah untuk indikator prokrastinasi akademik mahasiswa rata-rata persentase mencapai $8,33 \%$ atau dengan rata-rata frekuensi 2,5 mahasiswa.

12. Kategori sangat rendah untuk indikator prokrastinasi akademik mahasiswa rata-rata persentase mencapai $9,43 \%$ atau dengan ratarata frekuensi 2,8 mahasiswa.

\section{Kesimpulan}

Mahasiswa cenderung melakukan prokrastinasi akademik yang diidentifikasi melalui beberapa indikator antara lain keyakinan akan kemampuan, gangguan perhatian, faktor sosial, manajemen waktu, inisiatif pribadi, dan kemalasan. Penelitian ini dilakukan di kalangan mahasiswa dengan menggambarkan prokrastinasi akademik di kalangan mahasiswa. Diketahui setiap indikator memiliki persentase yang hampir sama kontribusinya dalam prokrastinasi akademik, yang dapat diartikan setiap indikator saling berkaitan dan mempengaruhi indikator lainnya. Indikator kemalasan menjadi penyebab tertinggi terjadi prokrastinasi akademik mahasiswa prodi Dharma Acarya dengan 20,3\%. Indikator terendah adalah faktor sosial dengan $13,9 \%$. data menunjukkan bahwa prokrastinasi akademik mahasiswa masuk dalam kategori tinggi dengan frekuensi 18 mahasiswa atau $60 \%$ dari seluruh responden yang berjumlah 30. Idealnya, prokrastinasi akademik berada dalam kategori rendah atau sangat rendah. Adanya kategori tinggi terhadap prokrastinasi Asosiasi Dosen \& Unit Penelitian dan Pengabdian Masyarakat akademik mahasiswa dapat menimbulkan permasalahn dalam proses pembelajaran. Semakin banyak tugas yang tertunda, semakin besar pula tingkat stress yang dapat dialami mahasiswa sehingga prises belajar semakin berjalan tidak kondusif. Kendala yang penulis hadapi adalah minimnya jumlah responden yang hanya berjumlah 30 mahasiswa saja. Peneliti berharap dapat kembali meneliti persentase prokrastinasi akademik mahasiswa prodi Dharma Acarya di seluruh perguruan tinggi lainnya agar memenuhi jumlah responden yang ideal.

Hasil penelitian ini dapat dijadikan sebagai informasi bagi perguruan tinggi agama Buddha prodi Dharma Acarya terkhusus sekolah Tinggi Agama Buddha Maha Prajna yang mayoritas alumninya berprofesi sebagai pengajar baik guru ataupun dosen, sebagai acuan dalam upaya meminimalisir permasalahan mahasiswa akibat dari prokrastinasi akademik. Dysfunctional Procrastination adalah prokrastinasi negatif yang memberi dampak negatif bagi mahasiswa, dosen dan kampus. Tentu hal ini perlu diperhatikan sebagai lanbgkah memajukan bidang akademik.

\section{Saran}

Penelitian tentang prokrastinasi akademik sudha banyak dilakukan dengan menunjukkan data atau hasil berupa adanya prokrastinasi pada mahasiswa. Penelitian ini perlu ditindaklajuti dalam bentuk penelitian rutin setiap satu tahun sekali, sebagai bentuk statistis perkembangan rokrastinasi akademik di suatu tempat perkuliahan. Idealnya dengan banyak penelitian dan tindakan pencegahan prokrastinasi akademik, persentase prokrastinasi akaemik mahasiwa akan menrun setiap tahunnya. 
Meski menrima mahasiswa baru yang mungkin memiliki prokrastinasi akademik sangat tinggi, namun penerapan penanggulangan prokrastinasi dilakukan diawal setiap mahasiswa baru memulai perkuliahan diajaran baru. Sehingga prokrastinasi tersebut dapat ditekan sejak dini.

\section{DAFTAR PUSTAKA}

Bruno, 1998. Stop Procrastination: Pahami dan Hentilcan Kebiasaan Anda Menunda-Nunda Waktu (Terjemahan: AR. H. Sitanggang). Jakarta: PT Gramedia Pustaka Utama

Burka, J. B. \& Yuen, L. M. (2008). Procrastination: Why You Do It, What To Do About It. Camridge: Da Capo Press

Burns, L. R., Dittman, K., Nguyen, N., \& Mitchelson, J. K. (2000). Academic procrastination, perfectionism, and control: Associations with vigilant and avoidant coping. Journal of Social Behavior and Personality, 5, 35-46

Ellis. A., \& Knaus, W.J. (2002). Overcoming Procrastination. New York: McGraw-Hill

Ferrari dan Morales. 2007. Perceptions of SelfConcept and Self-Presentation by Procrastinators: Further Evidence. The Spanish Journal of Psychology 10 (1): 32.

Ferrari, J., \& Tice, D. (2000). Procrastination as a selfhandicap for men and women: A taskavoidance strategy in a laboratory setting. Journal of Research in Personality, 34, 7383.

Ferrari, J.R. Johnson, J.L. \& Mc.Crown, W.G. 1995. Procrastinasi dan task avoidance, Theory, Research and Treathment. New York: Plenum Press

Ghufron, M. N, \& Risnawati, R. 2010. Teori-teori Psikologi. Yogyakarta: Ar-Ruzz Media

Ilfiandra. (2010). Penanganan Prokrastinasi Akademik Siswa Sekolah Menengah Atas: Konsep dan Aplikasi. Diunduh pada tanggal 28 Juli $2020 \quad$ dari http://www.osun.org//journalprokrastinasi.pdf. Mccloskey, j.d. (2011). Finally, My Thesis on Academic Procrastination. Thesis tidak diterbitkan. The University of Texas at Arlington.

Moore, R. Academic Procrastination and Course Performance among Developmental
Education Students, Journal Research and Teaching in Developmental Education 24 (2): 57.

Nugrasanti, Reni. (2006). Locus of Control dan Prokrastinasi Akademik Mahasiswa; Jurnal Provitae 2 No 1, Mei 2006. Jakarta: Yayasan Obor Indonesia.

Rivzi, A. Johana E. P, danSoetjipto, H,P. (1997).Pusat Kendali Dan Efikasi DiriSebagai Prediktor Prokastinasi Akademik Mahasiswa. Yogyakarta: Psikologika

Schraw, G., Watkinds, T., \& Olafson, L. (2007). Doing the Things We Do: A Grounded Theory of Academic Procrastination. Journal of Educational Psychology, 2007, Vol. 99, No. 1, 12-25

Solomon, L.J. \& Rothblum, E.D. (2005). Academic Procrastination: Frequency and CognitiveBehavioral Correlates". Journal of Counseling Psychology.Vol.31(504-510).

Wolters, C. A. (2003). Understanding Procrastination from a Selfregulated Learning Perspective. Journal of Educational Psychology, 95, 179-187.

Wulan, R. (2000). Hubungan antara Pengasuhan Orang Tua dengan Prokrastinasi Akademik pada Remaja SMU. Skripsi (tidak diterbitkan). Yogyakarta: Fakultas Psikologi Universitas Gadjah Mada.

Yudistiro. (2016). Hubungan Prokrastinasi Akademik dengan Prestasi Belajar pada Siswa yang Aktif dalam Kegiatan Ekstrakurikuler. Psikoborneo, 4 (2): 425-431. 